\title{
Extreme isotopologue disequilibrium in molecular SIMS species during SHRIMP geochronology
}

\author{
Charles W. Magee Jr. ${ }^{1,2}$, Martin Danišík ${ }^{3}$, and Terry Mernagh ${ }^{2,4}$ \\ ${ }^{1}$ Australian Scientific Instruments, 111/113 Gladstone St., Fyshwick, ACT 2609, Australia \\ ${ }^{2}$ Research School of Earth Sciences, Australian National University, Canberra, ACT 2600, Australia \\ ${ }^{3}$ GeoHistory Facility, John de Laeter Centre, TIGeR, Applied Geology, Curtin University, Perth, WA 6845, Australia \\ ${ }^{4}$ Geoscience Australia, Symonston, ACT 2609, Australia
}

Correspondence to: Charles W. Magee Jr. (cwmagee@gmail.com)

Received: 2 March 2016 - Discussion started: 11 April 2016

Revised: 27 September 2017 - Accepted: 28 September 2017 - Published: 6 December 2017

\begin{abstract}
The current limitation in the accuracy and precision of inter-element analysis in secondary ion mass spectrometry (SIMS) is the ability to find measurable quantities that allow relative differences in ionization and transmission efficiency of secondary ions to be normalized. In uraniumthorium-lead geochronology, the ability to make these corrections, or "calibrate" the data, results in an accuracy limit of approximately $1 \%$. This study looks at the ionization of uranium and thorium oxide species, which are traditionally used in $\mathrm{U}-\mathrm{Pb}$ calibration, to explore the conditions under which isotopologues, or molecular species whose composition differs only in the isotopic composition of one or more atoms in the molecule, remain in or deviate from equilibrium.

Isotopologue deficits of up to $0.2(200 \%$ ) below ideal mixing are observed in $\mathrm{UO}_{2}^{+}$species during SIMS gechronological analyses using the SHRIMP IIe SIMS instrument. These are identified by bombarding natural U-bearing minerals with an ${ }^{18} \mathrm{O}_{2}^{-}$primary beam. The large anomalies are associated with repeat analyses down a single SIMS sputtering crater (Compston et al., 1984), analysis of high-uranium, radiation-damaged zircon, and analysis of baddeleyite. Analysis of zircon under routine conditions yield $\mathrm{UO}_{2}^{+}$isotopologue anomalies generally within a few percent of equilibrium. The conditions under which the isotopologue anomalies are observed are also conditions in which the $\mathrm{UO}_{x}$-based corrections, or calibration, for relative $\mathrm{U}$ vs. $\mathrm{Pb}$ ionization efficiencies fail. The existence of these isotopologue anomalies suggest that failure of the various $\mathrm{UO}_{x}$ species to equilibrate with each other is the reason that none of them will successfully correct the $\mathrm{U} / \mathrm{Pb}$ ratio. No simple isotopologue-
\end{abstract}

based correction is apparent. However, isotopologue disequilibrium appears to be a more sensitive tool for detecting high-U calibration breakdowns than Raman spectroscopy, which showed sharper peaks for $\sim 37 \mathrm{Ma}$ high-uranium zircons than for reference zircons OG1 and Temora. U-Th$\mathrm{Sm} / \mathrm{He}$ ages were determined for aliquots of reference zircons OG1 (755 $\pm 71 \mathrm{Ma})$ and Temora (323 $443 \mathrm{Ma})$, suggesting that the broader Raman lines for the Temora reference zircons may be due to something other than accumulated radiation damage.

Isotopologue abundances for $\mathrm{UO}^{+}$and $\mathrm{ThO}^{+}$and their energy spectra are consistent with most or all molecular species being the product of atomic recombination when the primary beam impact energy is greater than $5.7 \mathrm{keV}$. This, in addition to the large $\mathrm{UO}_{2}^{+}$instrumentally generated isotopologue disequilibria, suggests that any attempts to use SIMS to detect naturally occurring isotopologue deviations could be tricky.

\section{Introduction}

Determining the timing of geologic events is a fundamental constraint for unravelling the history of our planet. In the 120 years since the discovery of radioactivity, the use of radioactive decay has been an increasingly versatile, accurate, and precise way of measuring geologic time. One of the major advances in this field was the invention of the SHRIMP (Sensitive High Resolution Ion MicroProbe), which has been used for $\mathrm{U}-\mathrm{Pb}$ geochronology of zircon for the last 34 years (Froude et al., 1983). 
The SHRIMP is a large-radius, magnetic sector secondary ion mass spectrometry (SIMS) instrument (Ireland et al., 2008). It features a low-impact-energy floating primary column optimized for Köhler illumination of a projection aperture onto the surface with a mass-filtered primary beam, a low-energy $\left(350 \mathrm{~V} \mathrm{~mm}^{-1}\right)$ initial extraction field, a quadrupole triplet for matching the secondary ion emittance to the mass spectrometer acceptance, and a large (1 m turning radius) $\mathrm{CQH}$ mass spectrometer with second-order focal aberration correction (Matsuda, 1974). The instrument used in this experiment is equipped with a single-electron multiplier as a detector; all data are ion counting on sequential mass peaks. The SHRIMP has been used to provide the geochronological foundations of thousands of papers, usually using a methodology best described several decades ago (Williams, 1998; Compston, et al., 1984).

A key requirement for successful SHRIMP U-Pb geochronology is accounting for the differential and variable secondary ionization yields of $\mathrm{U}$ and $\mathrm{Pb}$ in the SIMS source. The current method for doing this is the use of a calibration relating the detected ion ratio of $\mathrm{Pb}^{+} / \mathrm{U}^{+}$to the ratio of an oxidized molecular U-bearing ion to a reduced one. The most widely used calibration is a power law relationship between $\mathrm{Pb}^{+} / \mathrm{U}^{+}$and $\mathrm{UO}^{+} / \mathrm{U}^{+}$(Claoué-Long et al., 1995), but other calibrations using various combinations of $\mathrm{U}^{+}, \mathrm{UO}^{+}$, and $\mathrm{UO}_{2}^{+}$have been used (Stern and Amelin, 2003). These calibrations apply to both SHRIMP and other SIMS instruments used for geochronology.

There are some drawbacks to this technique. Firstly, the covariation is not exact, and after calibration there remains a residual error that is rarely better than $0.5 \%$. Secondly, it requires corrections for bulk composition for zircons with more than 2000 ppm U (Williams and Hergt, 2000; White and Ireland, 2012), or for minerals that exhibit complex solid solution, such as monazite (Gregory et al., 2007; Fletcher et al., 2010). Thirdly, some simple oxides, such as baddeleyite and rutile, exhibit orientation-related deviations from the calibration (Wingate and Compston, 2000; Schmitt et al., 2010; Taylor et al., 2012).

As the relationship between uranium oxide formation and $\mathrm{Pb}$ ionization efficiency at the SIMS sputter site is not clearly understood, an ${ }^{18} \mathrm{O}_{2}^{-}$primary beam was used to determine the source of the oxygen in the $\mathrm{UO}^{+}$species used for calibration (Magee et al., 2014). Previously, the use of ${ }^{18} \mathrm{O}$ implants in non-oxide species has been used for two purposes. Oxygen diffusion in either oxide or semiconductor matrices has been observed using an ${ }^{18} \mathrm{O}$ flood or ion implant (Kilner et al., 1996; Manning et al., 1997). In addition, ${ }^{18} \mathrm{O}$ implants have been used for quantifying behaviour of sputtered oxygen introduced by either a natural primary beam (Sobers Jr. et al., 2004) or by oxygen flooding (Franzreb et al., 2004). This study reverses the Sobers Jr. et al. (2004) method in which the ${ }^{18} \mathrm{O}$ implant is replaced with the stoichiometric natural oxygen composition $\left(99.8 \%{ }^{16} \mathrm{O}\right)$ of the natural target material, and the ${ }^{16} \mathrm{O}^{-}$primary beam used by Sobers Jr. et al. (2004) is replaced by a ${ }^{18} \mathrm{O}_{2}^{-}$primary beam. It is the first labelled oxygen SIMS experiment where an untreated natural mineral target is bombarded with an isotopically labelled primary oxygen beam, and the stoichiometry defines the ${ }^{16} \mathrm{O}$ content of the sputtered volume.

A description of the monoxide species formed in these experiments (Magee et al., 2014) showed that for primary energy greater than $5 \mathrm{keV}$, the relationships between uranium, thorium, and their monoxides were consistent with complete atomization and recombination (in the case of molecular species) during the sputtering process. However, the behaviour of more complicated molecular species, such as the actinide dioxides, was not considered there. This paper describes the ion abundances of the actinide dioxide species and discusses the possible meaning of the observed abundances.

One prediction of the atomization and recombination process is that the isotopologues of the molecular dioxide species should occur with abundances that are consistent with the isotopic ratio of the monoxide and elemental sputtered species. For example, if (as is the case in standard zircon geochronology) $\mathrm{U}^{16} \mathrm{O}$ and $\mathrm{U}^{18} \mathrm{O}$ are sputtered in equal proportion (Magee et al., 2014), then the predicted ratio of $\mathrm{U}^{16} \mathrm{O}_{2}$ to $\mathrm{U}^{16} \mathrm{O}^{18} \mathrm{O}$ to $\mathrm{U}^{18} \mathrm{O}_{2}$ is $1: 2: 1$. This study tests this prediction of isotopologue equilibrium, and tries to explain the observed deviations from it. The conclusions drawn are then applied to practical SIMS geochronology, in an attempt to propose methodologies that will improve analytical performance.

\section{Methods}

The experiments were performed on the SHRIMP IIe instrument at Geoscience Australia (Stern et al., 2009). Following the first "blank" experiment (see section A, below), the tank of (isotopically natural) high-purity oxygen gas usually used to feed the duoplasmatron was replaced with a tank of $99.9 \%{ }^{18} \mathrm{O}_{2}$ gas (Icon Isotope Services, Troy, NY). The primary beam Wein filter electrostatic voltage was then dropped to transmit mass 36 , selecting the ${ }^{18} \mathrm{O}_{2}^{-}$ion for sample bombardment. As the samples were all natural oxides, this instrumental setup yielded a situation where $99.7 \%$ of the sputtered oxygen originating from the sample is ${ }^{16} \mathrm{O}$, and essentially all the resputtered primary beam oxygen is ${ }^{18} \mathrm{O}$. No oxygen flooding was used, yielding a simple two-component system.

The analytical run table included standard uranium lead geochronology peaks: ${ }^{90} \mathrm{Zr}_{2}^{16} \mathrm{O}$ reference peak, a background position, ${ }^{204} \mathrm{~Pb},{ }^{206} \mathrm{~Pb},{ }^{207} \mathrm{~Pb},{ }^{208} \mathrm{~Pb},{ }^{232} \mathrm{Th}$, and ${ }^{238} \mathrm{U}$. In addition to the standard actinide oxides used for U$\mathrm{Pb}$ calibration (Williams, 1998), the ${ }^{18} \mathrm{O}$ isotopologues of those masses were also included: ${ }^{232} \mathrm{Th}^{16} \mathrm{O}(248),{ }^{232} \mathrm{Th}^{18} \mathrm{O}$ (250), ${ }^{238} \mathrm{U}^{16} \mathrm{O}$ (254), ${ }^{238} \mathrm{U}^{18} \mathrm{O}$ (256), ${ }^{238} \mathrm{U}^{16} \mathrm{O}_{2}$ (270), ${ }^{238} \mathrm{U}^{16} \mathrm{O}^{18} \mathrm{O}$ (272), and ${ }^{238} \mathrm{U}^{18} \mathrm{O}_{2}$ (274). For analytical session 130058, the $\mathrm{ThO}_{2}$ isotopologues were also counted, so 
additional peaks of ${ }^{232} \mathrm{Th}^{16} \mathrm{O}_{2}$ (264), ${ }^{232} \mathrm{Th}^{16} \mathrm{O}^{18} \mathrm{O}$ (266), and ${ }^{232} \mathrm{Th}^{18} \mathrm{O}_{2}$ (268) were collected.

Aside from the additional mass stations, and the isotopically labelled primary beam, analyses were run automatically using standard Geoscience Australia procedures. Ions are extracted from the duoplasmatron ion source at $10 \mathrm{kV}$, focused through the primary column, and subjected to an additional $680 \mathrm{~V}$ of acceleration between the extraction plate and the sample, for a total primary impact energy of $10680 \mathrm{~V}$. Secondary ions are initially extracted off the surface of the target at $680 \mathrm{~V}$ before acceleration to a total of $10 \mathrm{kV}$ for mass spectrometric analysis. The SHRIMP was set up with a $110 \mu \mathrm{m}$ source slit and a $100 \mu \mathrm{m}$ collector slit, yielding a $1 \%$ mass resolution $(\mathrm{M} / \Delta \mathrm{M})$ of 5000 or greater for all peaks. Data were collected in six scans through the run table on a single electron multiplier. Data were reduced using SQUID 2.5 (Ludwig, 2010). Analytical and data reduction procedures are described in detail elsewhere (Magee et al., 2012). The mounts analysed were a mix of standard $25 \mathrm{~mm}$ mounts and $35 \mathrm{~mm}$ "megamounts" (Ickert et al., 2008). Baddeleyite analyses were performed using the same instrumental setup and analytical run table.

The following experiments were performed.

\section{Experiment A: analytical "blank"}

Before the ${ }^{18} \mathrm{O}$ bottle was connected to the duoplasmatron, the run table with the ${ }^{18} \mathrm{O}$ species was run using standard, isotopically undisturbed oxygen with both zircon and baddeleyite targets (zircon: session 110056; baddeleyite: session 110057). The primary beam Wein filter was used to select mass 32 , so that the primary beam in this experiment (as is usually the case in standard SHRIMP II and SHRIMP RG analyses) was ${ }^{16} \mathrm{O}_{2}^{-}$. The purpose of this was to see if any unexpected mass interferences existed that would complicate interpretations of the ${ }^{18} \mathrm{O}$-bearing species. In session 110056, 25 grains of Temora-2 (Black et al., 2004) zircon were analysed, along with 22 grains of R-33 (Black et al., 2004) and 8 grains of OG1 (Stern et al., 2009). In 110057, an oriented Phalabowra baddeleyite mount from the original orientation work (Wingate and Compston, 2000) was analysed, with a dozen analyses on each of the four oriented megacrysts.

\section{Experiment B: standard zircon}

Four analytical sessions $(110061,110066,110088,110106)$ were run with standard zircon using the ${ }^{18} \mathrm{O}_{2}^{-}$primary beam. Two of these contained zircons of unknown age, the geochronological results of which are published in Laurie et al. (2016). The reference materials in those runs consisted of the following:

Session 110061: 24 Temora-2 and 21R-33.

Session 110066: 28 Temora-2 and 26 R-33.

Session 110088: 79 Temora-2 and 49 R-33.
Session 110106: 12 Temora, 6 R-33, 4 OG1.

Session 130056: 14 Temora.

Session 130058: 9 Temora.

\section{Experiment C: high-uranium zircon}

The zircon mount used in a recent study of the high- $\mathrm{U}$ effect (White and Ireland, 2012) was repolished and reanalysed using the ${ }^{18} \mathrm{O}_{2}^{-}$beam. These sessions were as follows:

Session 110067: 10 Temora and 16 Red Hill (Williams and Hergt, 2000; White and Ireland, 2012) zircons.

Session 130028: 10 Temora, 10 OG1, and 18 Raumid (Kostitsyn et al., 2007) zircons.

Session 130056: 37 Bishop Tuff (Ickert et al., 2015) zircons.

Session 130058: eight 100 Raumid and ten 119 Raumid zircons.

\section{Experiment D: baddeleyite}

Baddeleyite was analysed in session 110060 and 110065 . Twelve spots on each of four oriented sections of Phalabowra were analysed in session 110060. In 110065, 20 randomly oriented Phalabowra and 20 randomly oriented Kurinelli dolerite (Claoué-Long et al., 2008) grains were analysed.

\section{Experiment E: impact energy effect}

Five sessions were run using primary beam impact energies between 3.7 and $15.7 \mathrm{kV}$. The effect of impact energy on $\mathrm{Pb}$ ionization and the $\mathrm{U}-\mathrm{Pb}$ calibration is discussed previously (Magee et al., 2014). However the $\mathrm{UO}_{2}^{+}$species are not discussed there. The sessions, primary energy (add $\sim 680 \mathrm{~V}$ for impact energy) and analysed grains were as follows:

110098: 15 kV, 13 Temora, 6 R-33, 3 OG1.

110099: $12.5 \mathrm{kV}, 12$ Temora, 6 R-33, 4 OG1

110101: 5 kV, 12 Temora, 6 R-33, 4 OG1

110103: 3 kV, 10 Temora, 5 R-33, 3 OG-1

110105: $7.5 \mathrm{kV}, 12$ Temora, 6 R-33, 4 OG1

\section{Experiment F: repetitive downhole analysis test}

Several of the sessions listed above had one or two spots with repeated analyses down a single sputtering crater, under a variety of conditions. For monazite these were 1409-4 (three downhole analyses), 44069-1.1 (three downhole analyses), and 8153-1 (three downhole analyses); all is session 110064. Baddeleyite (110065) Phalabowra 1.1 (three). Zircon: 110066: Temora34.1 (three), R-36 (two), R-47.1 (three); 
110098 Tem-1.1 (four); 110099 Tem-14.1 (four); 110101 R33-18.1 (4); 110103 Tem53.1 (four); 110105 Tem-65 (two), all in session 110064 .

\section{Experiment G: monazite}

Session 110064 included multiple analyses of three popular monazite reference materials: 1409 (Stern and Berman, 2001), 8153 (Carson et al., 2008), and 44069 (Aleinikoff et al., 2006) were each analysed in 11 separate spots (one of each had the multiple downhole analyses described above).

\section{Experiment $\mathrm{H}: \mathrm{ThO}_{2}$ disequilibria}

In session 130058, the run table was further expanded to include all three major $\mathrm{ThO}_{2}$ isotopologues, with the intention of comparing $\mathrm{UO}_{2}$ and $\mathrm{ThO}_{2}$ isotopologic deviations. The run table containing these additional peaks was used to analyse the high-U Raumid zircons. The purpose of this experiment is to see whether the more variable charge state of $U$ causes different deviations to that of Th.

\section{Raman}

Laser Raman spectra were recorded on a Dilor ${ }^{\circledR}$ SuperLabram spectrometer equipped with a holographic notch filter, 600 and $1800 \mathrm{~g} \mathrm{~mm}^{-1}$ gratings, and a liquid $\mathrm{N}_{2}$ cooled, $2000 \times 450$ pixel CCD detector. The samples were illuminated with $514.5 \mathrm{~nm}$ laser excitation from a Melles Griot 543 Series argon ion laser, using $5 \mathrm{~mW}$ power at the sample surface, and a single $30 \mathrm{~s}$ accumulation. A $100 \times$ Olympus microscope objective was used to focus the laser beam and collect the scattered light. The focused laser spot on the samples was approximately $1 \mu \mathrm{m}$ in diameter. Wavenumbers are accurate to $\pm 1 \mathrm{~cm}^{-1}$ as determined by plasma and neon emission lines.

\section{Helium dating}

In order to more fully understand the Raman result of the reference zircons Temora 2 and OG1, conventional (U-Th$\mathrm{Sm}) / \mathrm{He}$ dating was performed on several whole OG1 and Temora 2 zircons using methodology described in Daniš́́k et al. (2012). Euhedral to subhedral single crystals were degassed at $\sim 1250{ }^{\circ} \mathrm{C}$ under ultra-high vacuum using a diode laser, and ${ }^{4} \mathrm{He}$ was measured by isotope dilution on a Pfeiffer Prisma QMS-200 mass spectrometer. Then the crystals were spiked with ${ }^{235} \mathrm{U}$ and ${ }^{230} \mathrm{Th}$, dissolved and analysed by isotope dilution for $\mathrm{U}$ and $\mathrm{Th}$ on solution ICP-MS. (U-Th$\mathrm{Sm}) / \mathrm{He}$ ages were corrected for alpha recoil following the procedure of Farley et al. (1996) assuming a homogeneous $\mathrm{U}-\mathrm{Th}$ distribution.

The (U-Th-Sm) / He dating was performed because, although the palaeoarchean OG1 has a crystallization age more than 8 times older than the Silurian Temora 2, it is possible that for much of that time the OG1 was at an elevated tem-

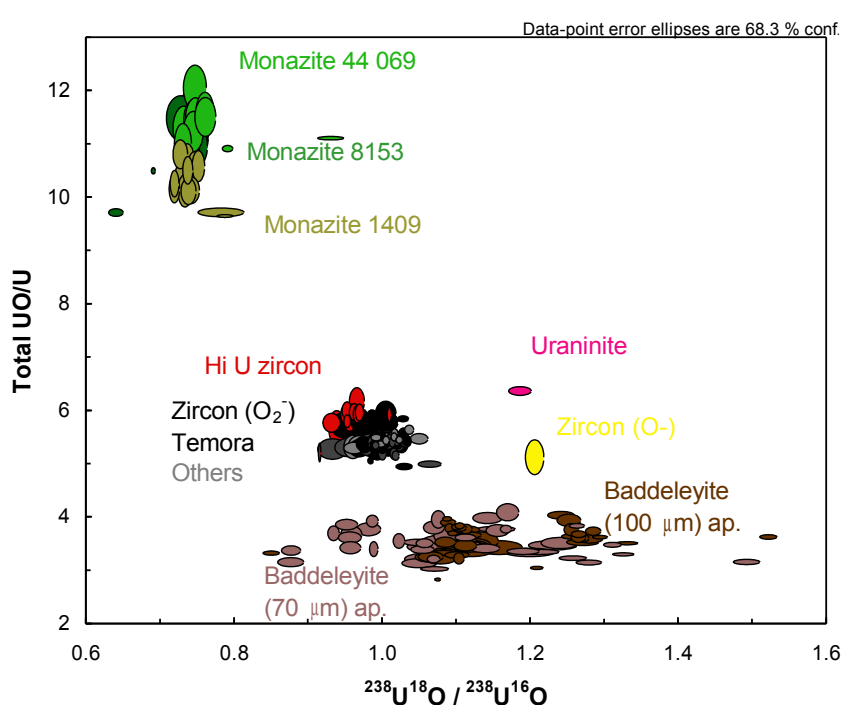

Figure 1. Plot of $\mathrm{U}^{18} \mathrm{O}^{+} / \mathrm{U}^{16} \mathrm{O}^{+}$vs. Total $\mathrm{UO}^{+}$ $\left(\mathrm{U}^{16} \mathrm{O}^{+}+\mathrm{U}^{18} \mathrm{O}^{+}\right) / \mathrm{U}^{+}$for various target minerals. Monazite sample identifications are given in the text. Two Kohler aperture sizes were used in baddeleyite analyses.

perature, where radiation damage could anneal out. Assuming this temperature threshold is similar to the He retention temperature of $\sim 150-220^{\circ} \mathrm{C}$ (Guenthner et al., 2013), this experiment was performed to see if a (U-Th-Sm) / He age much younger than the crystallization age could explain the Raman results.

\section{Results}

The relation between total $\mathrm{UO}^{+} / \mathrm{U}^{+}$and the $\mathrm{U}^{18} \mathrm{O}^{+} / \mathrm{U}^{16} \mathrm{O}^{+}$for different minerals is shown in Fig. 1. The relation between total $\mathrm{UO}^{+} / \mathrm{U}^{+}$and the $\mathrm{U}^{18} \mathrm{O}^{+} / \mathrm{U}^{16} \mathrm{O}^{+}$based on impact energy was shown in Magee et al. (2014).

The predicted ratios of $\mathrm{U}^{18} \mathrm{O}_{2}^{+}$and $\mathrm{U}^{16} \mathrm{O}^{18} \mathrm{O}^{+}$relative to $\mathrm{U}^{16} \mathrm{O}_{2}^{+}$were calculated from the observed $\mathrm{U}^{18} \mathrm{O}^{+} / \mathrm{U}^{16} \mathrm{O}^{+}$ ratio, and compared to the observed ratios. For any observed $\mathrm{U}^{18} \mathrm{O}^{+} / \mathrm{U}^{16} \mathrm{O}^{+}$ratio, $R$, the equilibrium fractions of the dioxide species are

$\mathrm{U}^{16} \mathrm{O}_{2}:(1 /(R+1))^{2}$;

$\mathrm{U}^{18} \mathrm{O}_{2}:(R /(R+1))^{2}$;

$\mathrm{U}^{16} \mathrm{O}^{18} \mathrm{O}: 2 \cdot 1 /(R+1) \cdot R /(R+1)$.

The observed $\mathrm{U}^{18} \mathrm{O}_{2}^{+}$and $\mathrm{U}^{16} \mathrm{O}^{18} \mathrm{O}^{+}$and $\mathrm{U}^{16} \mathrm{O}_{2}^{+}$were then used to calculate delta values:

$\Delta 272$

$=\left(\right.$ Observed $\mathrm{U}^{16} \mathrm{O}^{18} \mathrm{O}^{+} / \mathrm{U}^{16} \mathrm{O}_{2}^{+}-$Predicted $\left.\mathrm{U}^{16} \mathrm{O}^{18} \mathrm{O}^{+} / \mathrm{U}^{16} \mathrm{O}_{2}^{+}\right) /$

(Predicted $\mathrm{U}^{16} \mathrm{O}^{18} \mathrm{O}^{+} / \mathrm{U}^{16} \mathrm{O}_{2}^{+}$) 
Table 1. Summary of isotopologue deviations for analytical sessions.

\begin{tabular}{|c|c|c|c|c|c|c|c|c|c|c|c|c|}
\hline Experiment & Session & Sample & Mineral & Feature & $\begin{array}{r}\mathrm{UO}^{+} / \\
\mathrm{U}^{+}\end{array}$ & \pm & $\begin{array}{r}\mathrm{U}^{18} \mathrm{O}^{+} / \\
\mathrm{U}^{16} \mathrm{O}^{+}\end{array}$ & \pm & $\begin{array}{r}\Delta 272 \\
(\%)\end{array}$ & $\pm \%$ & $\begin{array}{r}\Delta 274 \\
(\%)\end{array}$ & $\pm \%$ \\
\hline A: ${ }^{16} \mathrm{O}$ beam & 110056 & Temora & zircon & reference & 6.2 & 0.11 & $9.32 \times 10^{-4}$ & $1.00 \times 10^{-4}$ & 8.6 & 15.2 & -1159 & 1732 \\
\hline A: ${ }^{16} \mathrm{O}$ beam & 110056 & R33 & zircon & reference & 6.08 & 0.19 & $8.84 \times 10^{-4}$ & $8.25 \times 10^{-5}$ & 14.2 & 14.8 & -1645 & 3219 \\
\hline A: ${ }^{16} \mathrm{O}$ beam & 110056 & OG1 & zircon & reference & 6.08 & 0.14 & $9.14 \times 10^{-4}$ & $5.08 \times 10^{-5}$ & 19 & 12 & -1052 & 1792 \\
\hline A: ${ }^{16} \mathrm{O}$ beam & 110057 & Phalabowra & baddeleyite & reference & 3.49 & 0.24 & $9.35 \times 10^{-4}$ & $1.28 \times 10^{-4}$ & 5.9 & 12.7 & 48.6 & 2396 \\
\hline B: Standard & 110061 & Temora & zircon & reference & 5.38 & 0.06 & 1.00 & 0.01 & -1.9 & 0.7 & 1.2 & 1.5 \\
\hline B: Standard & 110061 & R33 & zircon & reference & 5.37 & 0.05 & 1.00 & 0.02 & -1.8 & 1.7 & 0.9 & 1.5 \\
\hline B: Standard & 110066 & Temora & zircon & reference & 5.4 & 0.07 & 1.00 & 0.02 & -1.1 & 1.0 & 2.2 & 1.4 \\
\hline B: Standard & 110066 & R33 & zircon & reference & 5.39 & 0.06 & 1.00 & 0.01 & -1.6 & 0.9 & 1.5 & 1.4 \\
\hline B: Standard & 110088 & Temora & zircon & reference & 5.33 & 0.11 & 1.02 & 0.01 & -1.1 & 0.8 & 1.5 & 1.0 \\
\hline B: Standard & 110088 & R33 & zircon & reference & 5.35 & 0.12 & 1.02 & 0.02 & -1.4 & 0.7 & 1.5 & 1.1 \\
\hline B: Standard & 110088 & Can & zircon & unknown & 5.46 & 0.18 & 1.02 & 0.03 & -1.5 & 0.4 & 1.5 & 0.7 \\
\hline B: Standard & 110088 & M735 & zircon & unknown & 5.4 & 0.11 & 1.02 & 0.02 & -0.9 & 0.7 & 1.6 & 1.3 \\
\hline B: Standard & 110088 & M750 & zircon & unknown & 5.35 & 0.09 & 1.02 & 0.01 & -1.1 & 0.7 & 1.9 & 0.8 \\
\hline B: Standard & 110088 & M736 & zircon & unknown & 5.36 & 0.11 & 1.02 & 0.02 & -1.2 & 0.6 & 1.3 & 0.7 \\
\hline B: Standard & 110106 & Temora & zircon & reference & 6.3 & 0.14 & 1.01 & 0.01 & -0.4 & 1.4 & 1.5 & 1.4 \\
\hline B: Standard & 130056 & Temora & zircon & reference & 6.16 & 0.46 & 1.09 & 0.03 & -0.9 & 0.04 & 0.4 & 0.7 \\
\hline B: Standard & 130058 & Temora & zircon & reference & 6.46 & 0.09 & 1.03 & 0.02 & -2.3 & 0.8 & 4.2 & 1.4 \\
\hline B: Standard & 130058 & OG1 & zircon & reference & 6.67 & 0.21 & 1.02 & 0.03 & -1.7 & 1.2 & 3.5 & 1.5 \\
\hline C: High U & 110067 & Temora & zircon & reference & 5.76 & 0.02 & 0.98 & 0.02 & -1.4 & 0.9 & 1.4 & 1.2 \\
\hline C: High U & 110067 & Red Hill & zircon & $\begin{array}{l}\text { all: average } \\
=4868 \mathrm{ppm}\end{array}$ & 5.83 & 0.21 & 0.96 & 0.02 & -1.4 & 0.7 & 3.8 & 2.3 \\
\hline C: High U & 110067 & Red Hill & zircon & $\begin{array}{l}>2500 \mathrm{ppm}: \\
\text { average }=5665\end{array}$ & 5.82 & 0.23 & 0.96 & 0.02 & -1.5 & 8.0 & 4.2 & 2.4 \\
\hline C: High U & 130028 & Temora & zircon & reference & 6.46 & 0.09 & 1.03 & 0.02 & -2.3 & 0.8 & 4.2 & 1.4 \\
\hline C: High U & 130028 & OG1 & zircon & reference & 6.45 & 0.21 & 1.02 & 0.03 & -1.7 & 1.2 & 3.5 & 1.5 \\
\hline C: High U & 130028 & Raumid 100 & zircon & $\begin{array}{l}\text { all: average } \\
=3828 \mathrm{ppm}\end{array}$ & 6.40 & 0.27 & 1.00 & 0.05 & -1.7 & 1.2 & 5.6 & 1.0 \\
\hline C: High U & 130028 & Raumid 100 & zircon & $\begin{array}{l}>2500 \mathrm{ppm}: \\
\text { average }=4600\end{array}$ & 6.38 & 0.30 & 0.99 & 0.05 & -1.3 & 0.7 & 5.6 & 1.2 \\
\hline C: High U & 130028 & Raumid 119 & zircon & $\begin{array}{l}\text { all: average } \\
=6376\end{array}$ & 6.63 & 0.19 & 1.03 & 0.03 & -1.5 & 0.8 & 6.4 & 1.8 \\
\hline C: High U & 130028 & Raumid 119 & zircon & $>2500$ ppm: 6968 & 6.57 & 0.25 & 1.01 & 0.03 & -1.4 & 0.7 & 6.8 & 1.9 \\
\hline C: High U & 130056 & Temora & zircon & reference & 6.24 & 0.46 & 1.09 & 0.03 & -0.9 & 0.4 & 0.4 & 0.7 \\
\hline C: High U & 130056 & BT & zircon & $\begin{array}{l}\text { all: average } \\
=2511\end{array}$ & 6.37 & 0.29 & 1.07 & 0.03 & -0.6 & 0.4 & 0.9 & 0.7 \\
\hline C: High U & 130056 & BT & zircon & $\begin{array}{l}>2500 \mathrm{ppm} \\
\text { average }=2952\end{array}$ & 6.37 & 0.31 & 1.07 & 0.03 & -0.5 & 0.3 & 0.8 & 0.3 \\
\hline D: Baddeleyite & 110060 & Phalabowra & baddeleyite & reference & 3.55 & 0.23 & 1.14 & 0.08 & -13 & 2.3 & 0.5 & 2.8 \\
\hline D: Baddeleyite & 110065 & Phalabowra & baddeleyite & reference & 3.43 & 0.24 & 1.11 & 0.15 & -11.3 & 3.8 & 1.0 & 3.9 \\
\hline D: Baddeleyite & 110065 & Kur & baddeleyite & unknown & 3.59 & 0.26 & 1.10 & 0.11 & -12 & 2.7 & -0.5 & 3.4 \\
\hline E: Impact energy & 110098 & Temora & zircon & $15 \mathrm{kV}$ & 5.15 & 0.12 & 0.99 & 0.01 & -0.3 & 1.3 & 0.9 & 1.1 \\
\hline E: Impact energy & 110099 & Temora & zircon & $12.5 \mathrm{kV}$ & 5.16 & 0.05 & 1.00 & 0.01 & -0.9 & 0.8 & 1.1 & 0.9 \\
\hline E: Impact energy & 110101 & Temora & zircon & $5 \mathrm{kV}$ & 7.19 & 0.14 & 1.16 & 0.90 & 0.9 & 0.8 & 2.5 & 1.2 \\
\hline E: Impact energy & 110103 & Temora & zircon & $3 \mathrm{kV}$ & 11.6 & 0.39 & 1.38 & 0.02 & -0.4 & 3.1 & 0.2 & 8.0 \\
\hline E: Impact energy & 110105 & Temora & zircon & $7.5 \mathrm{kV}$ & 6.68 & 0.10 & 1.05 & 0.01 & 0.1 & 1.0 & 2.3 & 1.3 \\
\hline G: Monazite & 110064 & 1409 & monazite & reference & 10.4 & 0.25 & 0.73 & 0.01 & 1.4 & 0.3 & 27 & 2.9 \\
\hline G: Monazite & 110064 & 44069 & monazite & reference & 11.4 & 0.27 & 0.74 & 0.10 & 1.4 & 0.3 & 21 & 3.4 \\
\hline G: Monazite & 110064 & 8153 & monazite & reference & 11.12 & 0.20 & 0.74 & 0.01 & 2.0 & 0.3 & 25 & 2.1 \\
\hline
\end{tabular}

$\Delta 274$

$=\left(\right.$ Observed $\mathrm{U}^{18} \mathrm{O}_{2}^{+} / \mathrm{U}^{16} \mathrm{O}_{2}^{+}-$Predicted $\left.\mathrm{U}^{18} \mathrm{O}_{2}^{+} / \mathrm{U}^{16} \mathrm{O}_{2}^{+}\right) /$

(Predicted $\mathrm{U}^{18} \mathrm{O}_{2}^{+} / \mathrm{U}^{16} \mathrm{O}_{2}^{+}$).

A summary of results is listed in Table 1, while the full analysis-by-analysis results are listed in the Supplement.

\section{Experiment A: analytical blank (standard oxygen instead of ${ }^{18} \mathrm{O}$ )}

110056: for the Temora zircons, the total $\mathrm{UO}^{+} / \mathrm{U}^{+}$was about 6.2 (Supplement). $\mathrm{U}^{18} \mathrm{O}^{+} / \mathrm{U}^{16} \mathrm{O}^{+}$ratio averaged about $9.3 \times 10^{-4}$, about half the natural ${ }^{18} \mathrm{O} /{ }^{16} \mathrm{O}$ ratio (Fig. 1). This is consistent with about half the oxygen coming from the natural abundance sample, and half from the pure ${ }^{16} \mathrm{O}_{2}$ beam (Magee et al., 2014). The weighted mean $\Delta 272$ is positive, $0.090 \pm 0.032(1 \sigma)$. This indicates an interference on 
$\mathrm{U}^{16} \mathrm{O}^{18} \mathrm{O}^{+}$which increases its intensity by about $10 \%$. However, without ${ }^{18} \mathrm{O}_{2}$ feeding the duoplasmatron, $\mathrm{U}^{16} \mathrm{O}^{18} \mathrm{O}^{+}$is a very low intensity peak (generally less than $10 \mathrm{cps}$ ), so this interference is, on average, less than $1 \mathrm{cps}$. As count rates on $\mathrm{U}^{16} \mathrm{O}^{18} \mathrm{O}^{+}$using the ${ }^{18} \mathrm{O}$ beam were 1000 times higher, this minor excess is sufficiently small to be ignored when processing the ${ }^{18} \mathrm{O}$ primary beam data in the experiments below, where it will contribute less than $1 \%$.

The expected $\mathrm{U}^{18} \mathrm{O}_{2}^{+}$counts are less than one millionth of the $\mathrm{U}^{16} \mathrm{O}_{2}^{+}$counts, and only $100000 \mathrm{U}^{16} \mathrm{O}_{2}^{+}$counts were collected. Therefore, we expect a fraction of a $\mathrm{U}^{18} \mathrm{O}_{2}^{+}$count, and the $\Delta 274$ is dominated by counting noise on the background. Any interfering peak present is negligible.

110057: Although the total $\mathrm{UO}^{+} / \mathrm{U}^{+}$ratio for baddeleyite was much lower (a mean of 3.46 , but scattered from just under 3 to almost 4), the same experiment performed on baddeleyite yielded broadly similar results; the $\mathrm{U}^{18} \mathrm{O}^{+} / \mathrm{U}^{16} \mathrm{O}^{+}$ratio averaged about $9.4 \times 10^{-4}$, and the weighted mean $\Delta 272$ is positive but somewhat smaller than for zircon, $0.044 \pm 0.049 \%$. This puts it within error of both zero and the zircon value. Once again, $\Delta 274$ is dominated by counting noise on the background, as the expected value is a fraction of a count.

\section{Experiment B: standard zircons}

The mean results for typical reference material and unknown zircons are shown in Table 1. These zircons showed a small but consistent negative D272 deviation, with a mean value of $-0.014 \pm 0.005$. There was also a small but consistent positive D274 deviation of $0.018 \pm 0.010$. The range and uncertainty of 79 Temora analyses is shown in Fig. 2. No statistically significant isotopologue disequilibrium trends related to age are observed, but only one session (130058) had OG1 grains analysed, and the extreme age of this reference material (Stern et al., 2009) dominates any age-related statistics. The geochronologic results from unknowns M750 and M736 analysed in session 110088 are given in Laurie et al., (2016) alongside ID-TIMS results for the same samples. The agreement between the SHRIMP ages and the IDTIMS ages for these samples suggests that the ${ }^{18} \mathrm{O}_{2}^{-}$primary beam introduces no statistically significant geochronological bias.

\section{Experiment C: high-uranium zircon}

Two of three high-uranium samples, the Triassic Red Hill and the Eocene Raumid, exhibited a $\Delta 274$ excess of up to 0.1 (Fig. 3a, b). The Pleistocene Bishop Tuff showed no such deviation (Fig. 3c). The Red Hill and Raumid also showed apparent excess radiogenic $\mathrm{Pb}$ (the "High U effect"; Williams and Hergt, 2000, but this effect was not evident in the Bishop Tuff samples; Chamberlain et al., 2014; Ickert et al., 2015). There is not a strong correlation between degree of $\Delta 274$

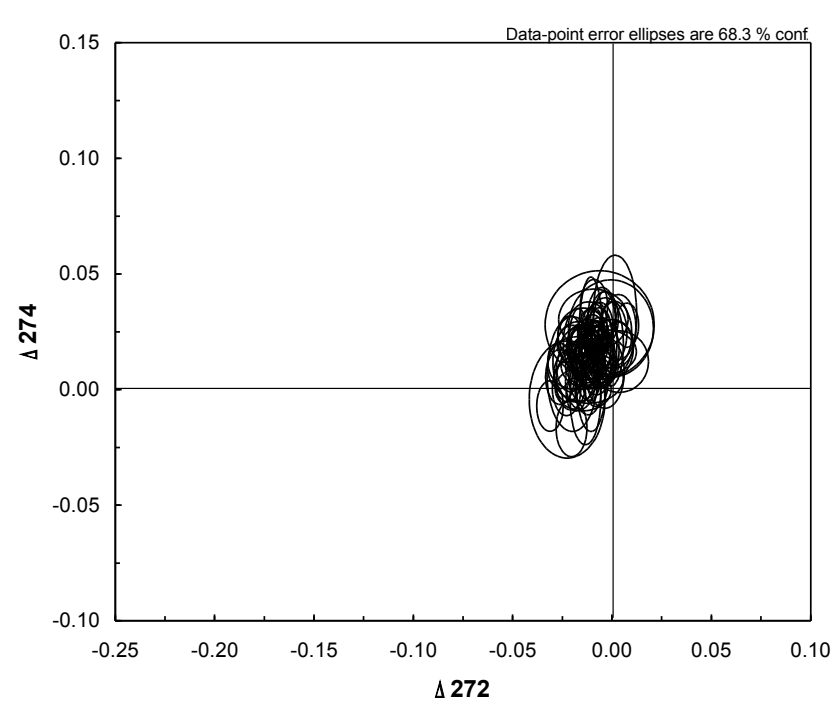

Figure 2. $\Delta 272$ vs. $\Delta 274$ plots for zircon analyses under standard operating conditions for SHRIMP geochronology.
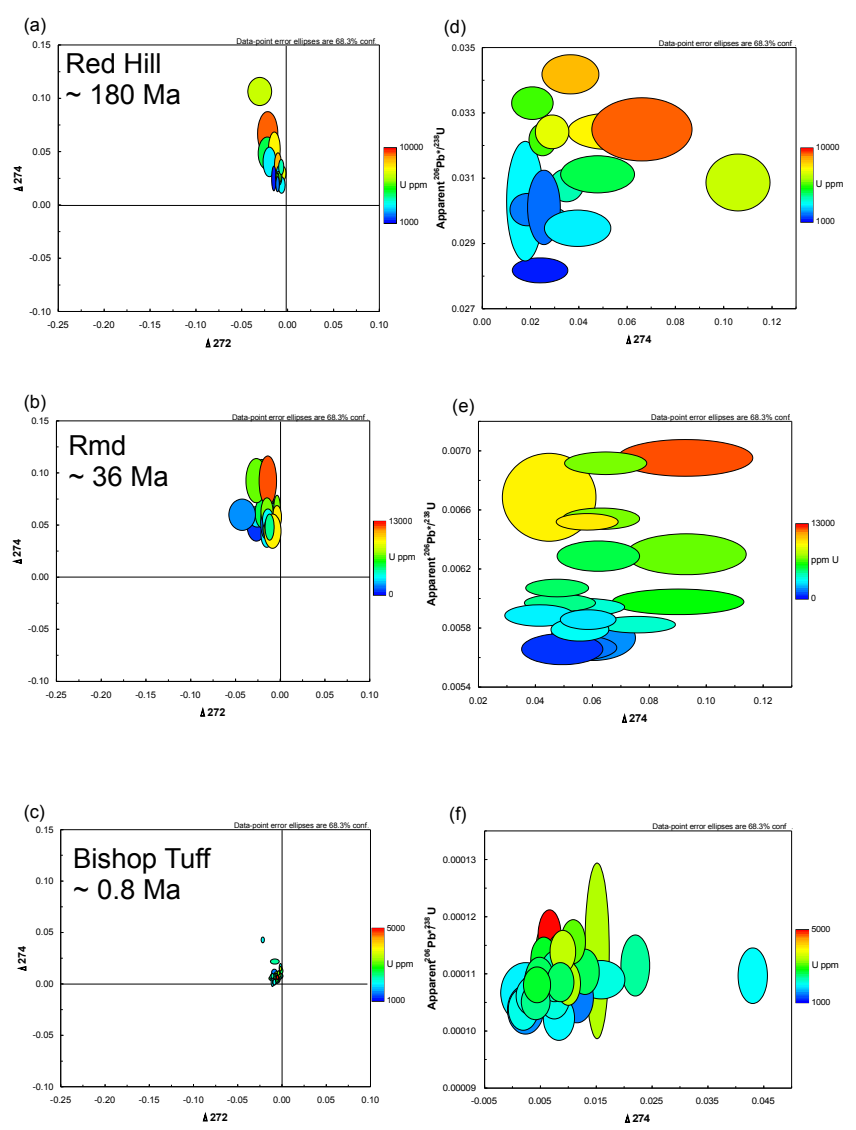

Figure 3. $(\mathbf{a}, \mathbf{b}, \mathbf{c}) \Delta 272$ vs. $\Delta 274$ plots for analyses of highuranium zircons of three different ages. (d, e, f) Apparent ${ }^{206} \mathrm{~Pb} /{ }^{238} \mathrm{U}$ ratio vs. $\Delta 274$, colour coded for $\mathrm{U}$ content, for highuranium zircons of three different ages. 

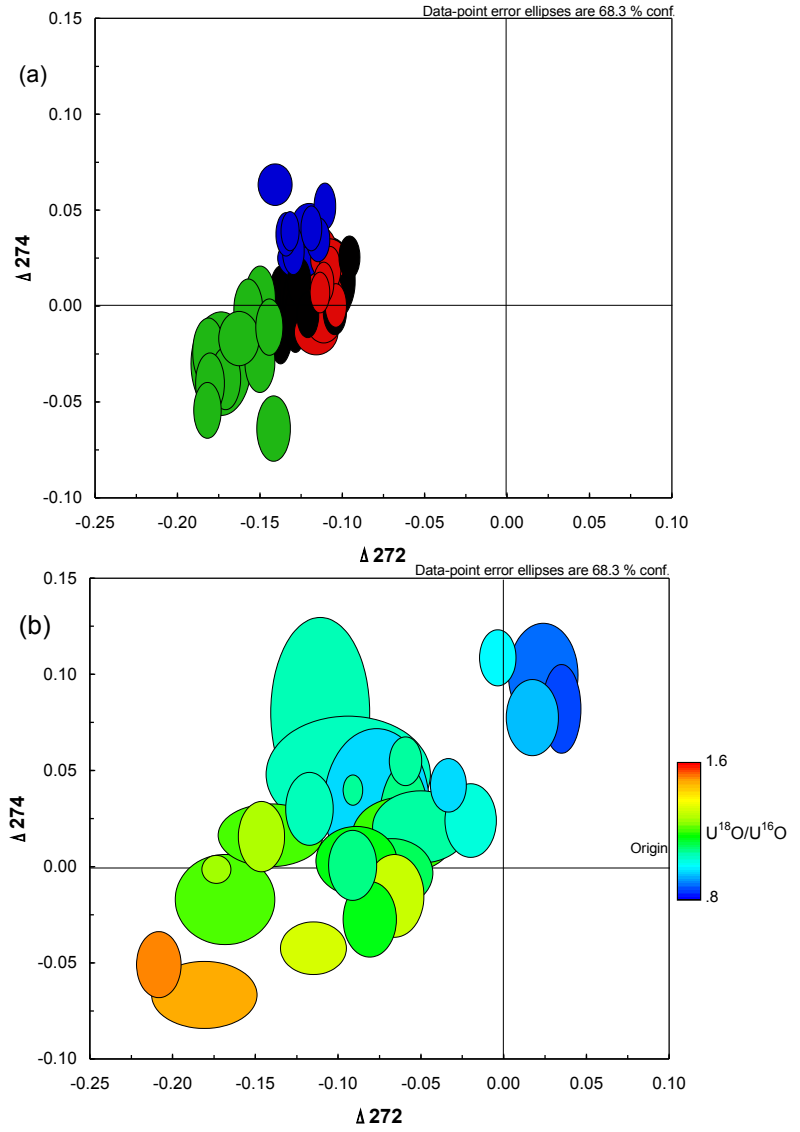

Figure 4. $\Delta 272$ vs. $\Delta 274$ plots for baddeleyite. (a) Four oriented megacrysts with repeated measurements on each. (b) Randomly oriented unknowns.

anomaly and degree of excess apparent radiogenic ${ }^{206} \mathrm{~Pb}$ (Fig. 3d-f).

\section{Experiment D: baddeleyite}

The results of the baddeleyite experiments are shown in Fig. 4. There are moderate to extreme negative $\Delta 272$ anomalies present. In addition, although the mean $\Delta 274$ is close to zero (Table 1), this belies substantial variation, between -0.07 and +0.11 , and many times the intra spot uncertainty (Fig. 4). There is a strong correspondence between the degree of negative $\Delta 272$ and sign of $\Delta 274$, and the overall $\mathrm{U}^{18} \mathrm{O}^{+} / \mathrm{U}^{16} \mathrm{O}^{+}$ratio. In the analyses of the oriented crystal fragments (Fig. 4a), there is good overall agreement between most analyses of each segment, but large differences between them. These orthogonally mounted sections (Wingate and Compston, 2000) do not show the low $\mathrm{U}^{18} \mathrm{O}^{+} / \mathrm{U}^{16} \mathrm{O}^{+}$ and high $\Delta 272$ and $\Delta 274$ results that were revealed from analysing randomly oriented crystals (Fig. 4b).

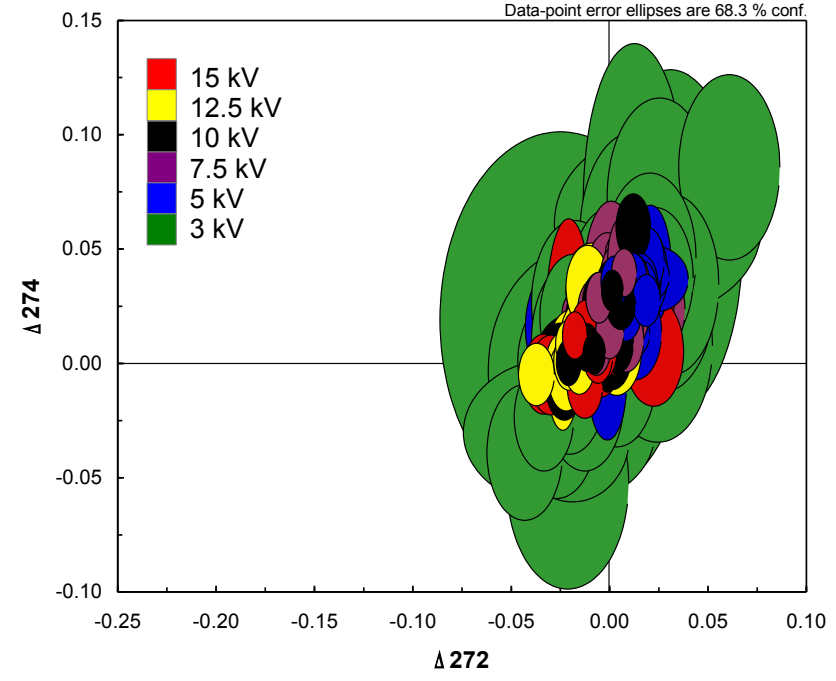

Figure 5. $\Delta 272$ vs. $\Delta 274$ plots for zircon analyses at $3-15 \mathrm{kV}$ primary energies. Repeated analyses in the same sputter crater are lighter colours. Colour coding by impact energy is the same as for previous figures. Add $680 \mathrm{~V}$ for impact energy.

\section{Experiment E: impact energy}

The results of the impact energy experiments for primary energy between 3 and $15 \mathrm{kV}$ are shown in Fig. 5. The $3 \mathrm{kV}$ results have poor counting stats due to the low sputter yield and primary beam current. For the rest of the analyses there was a slight trend to more negative $\Delta 272$ and $\Delta 274$ with increasing impact energy (Fig. 5).

\section{Experiment F: downhole analyses}

Additional analyses in a single spot were performed at a variety of primary ion energies between 3 and $15 \mathrm{kV}$ (Supplement). Acquisitions were manually started at the end of each previous analysis without moving the stage or retuning the secondary or primary beams. For energies below $10 \mathrm{kV}$, the additional measurements downhole resulted in a slight increase in $\Delta 272$ and a larger increase in $\Delta 274$ (Fig. 6a), although the poor counting stats on the $3 \mathrm{kV}$ experiment reduces the statistical significance for those results.

For a primary energy of $10 \mathrm{kV}$ and up, the repeated downhole analyses resulted in a slight decrease in $\Delta 272$, and a slight increase in $\Delta 274$. So the repeated downhole analyses in both instances moved away from the origin, and the location of standard, well-behaved analyses, but in different directions.

Figure $6 \mathrm{~b}$ shows that a scan-by-scan breakdown of multiple downhole analyses can detect when the analyses "fall off" the calibration, an effect known since the early days of SHRIMP (Compston et al., 1984). This fall-off corresponds with a minimum in the $\mathrm{U}^{18} \mathrm{O}^{+} / \mathrm{U}^{16} \mathrm{O}^{+}$ratio. It is these off- 


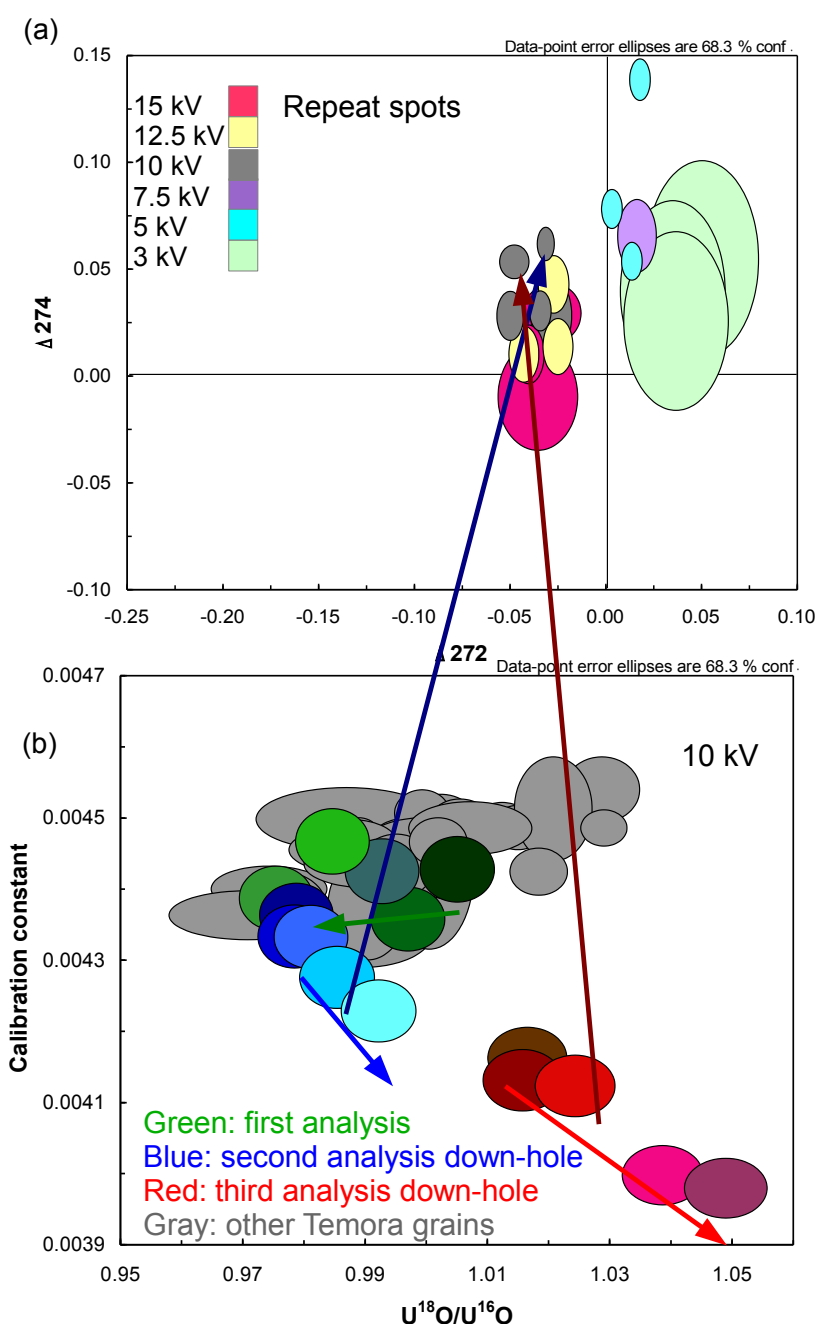

Figure 6. (a) $\Delta 272$ vs. $\Delta 274$ plots for multiple zircon analyses down the same hole under a variety of primary acceleration energies. (b) $\mathrm{U}^{18} \mathrm{O}^{+} / \mathrm{U}^{16} \mathrm{O}^{+}$vs. calibration constant on a scan-byscan basis for three downhole analyses. Grey ellipses are singlescan data for individual, non-repeated analyses.

calibration analyses which have the slightly lower $\Delta 272$ and slightly higher $\Delta 274$ values, compared to the on-calibration scans.

\section{Experiment G: monazite}

All monazite analyses showed extreme $\Delta 274$ anomalies, which were different between monazites of different composition. As no monazite analyses were performed using a standard oxygen primary beam, a composition-related interference cannot be ruled out, so no further interpretation will be done with these data.

\section{Experiment $\mathrm{H}$ : $\mathrm{ThO}_{2}$ isotopologue disequilibrium}

$\mathrm{ThO}_{2}$ isotopologue deviations were calculated in the same way as the $\mathrm{UO}_{2}$ isotopologue deviations.

The predicted ratios of $\mathrm{Th}^{18} \mathrm{O}_{2}$ and $\mathrm{Th}^{16} \mathrm{O}^{18} \mathrm{O}$ relative to $\mathrm{Th}^{16} \mathrm{O}_{2}$ were calculated from the observed $\mathrm{Th}^{18} \mathrm{O}^{+} / \mathrm{Th}^{16} \mathrm{O}^{+}$ratio, and compared to the observed ratios. For any observed $\mathrm{Th}^{18} \mathrm{O}^{+} / \mathrm{Th}^{16} \mathrm{O}^{+}$ratio, $R$, the equilibrium fractions of the dioxide species are

$\mathrm{Th}^{16} \mathrm{O}_{2}:(1 /(R+1))^{2}$;

$\mathrm{Th}^{18} \mathrm{O}_{2}:(R /(R+1))^{2}$;

$\mathrm{Th}^{16} \mathrm{O}^{18} \mathrm{O}: 2 \cdot 1 /(R+1) \cdot R /(R+1)$.

The observed $\mathrm{Th}^{18} \mathrm{O}_{2}$ and $\mathrm{Th}^{16} \mathrm{O}^{18} \mathrm{O}$ and $\mathrm{Th}^{16} \mathrm{O}_{2}$ were then used to calculate delta values:

$$
\begin{aligned}
\Delta & 266 \\
= & \left(\text { ObservedTh }{ }^{16} \mathrm{O}^{18} \mathrm{O} / \mathrm{Th}^{16} \mathrm{O}_{2}-\text { PredictedTh }{ }^{16} \mathrm{O}^{18} \mathrm{O} / \mathrm{Th}^{16} \mathrm{O}_{2}\right) / \\
& \left(\text { PredictedTh }{ }^{16} \mathrm{O}^{18} \mathrm{O} / \mathrm{Th}^{16} \mathrm{O}_{2}\right) \\
\Delta & 268 \\
= & \left(\text { ObservedTh }{ }^{18} \mathrm{O}_{2} / \mathrm{Th}^{16} \mathrm{O}_{2}-\text { PredictedTh }{ }^{18} \mathrm{O}_{2} / \mathrm{Th}^{16} \mathrm{O}_{2}\right) / \\
& \left(\text { PredictedTh }{ }^{18} \mathrm{O}_{2} / \mathrm{Th}^{16} \mathrm{O}_{2}\right) .
\end{aligned}
$$

\section{Raman}

The possible correlation of a D274 anomaly with the breakdown of the calibration due to high $\mathrm{U}$ led us to further investigate the radiation dosage and damage in the Raumid zircons relative to our reference zircons OG1 and Temora. Raman measurements were made on the high-U Raumid zircons, to determine if their high actinide contents had produced enough damage to broaden the Raman peaks. so that the Raumid results could be compared to $\mathrm{U}-\mathrm{Pb}$ reference material. The results are given in Table 2 and Fig. 7. The Raman peak widths were broader than OG1 and similar to Temora.

\section{Helium}

(U-Th-Sm) / He dating was performed on several Temora 2 and OG1 grains, in order to better constrain the radiation history of these reference materials, and to estimate their relative radiation damage histories. Single-grain (UTh-Sm) / He ages for OG1 range from $677.5 \pm 36.3$ to $815.5 \pm 44.6 \mathrm{Ma}(n=6$; average: $755 \pm 71 \mathrm{Ma})$ and are by $\sim 400 \mathrm{Myr}$ older than (U-Th-Sm) / He ages of Temora 2, which range from $287.9 \pm 15.3$ to $370.6 \pm 19.8 \mathrm{Ma}(n=5$; average: $323 \pm 43 \mathrm{Ma}$ ) (Table 3). These results indicate that OG1 accumulated radiation damage for about twice as long as Temora 2, despite having a crystallization age 8 times older. 


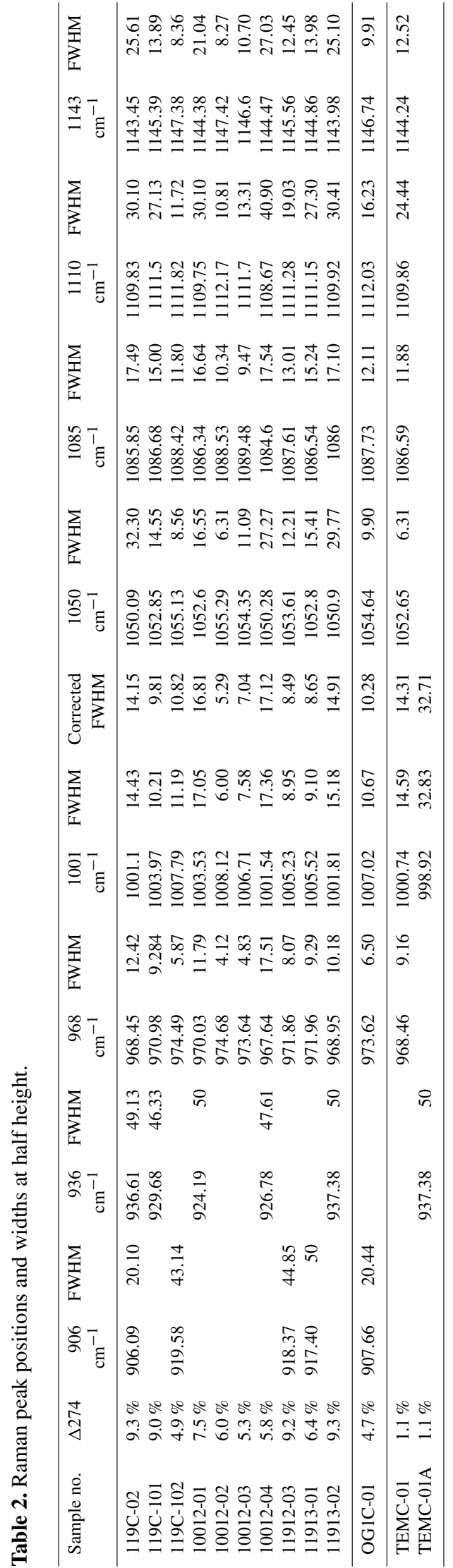

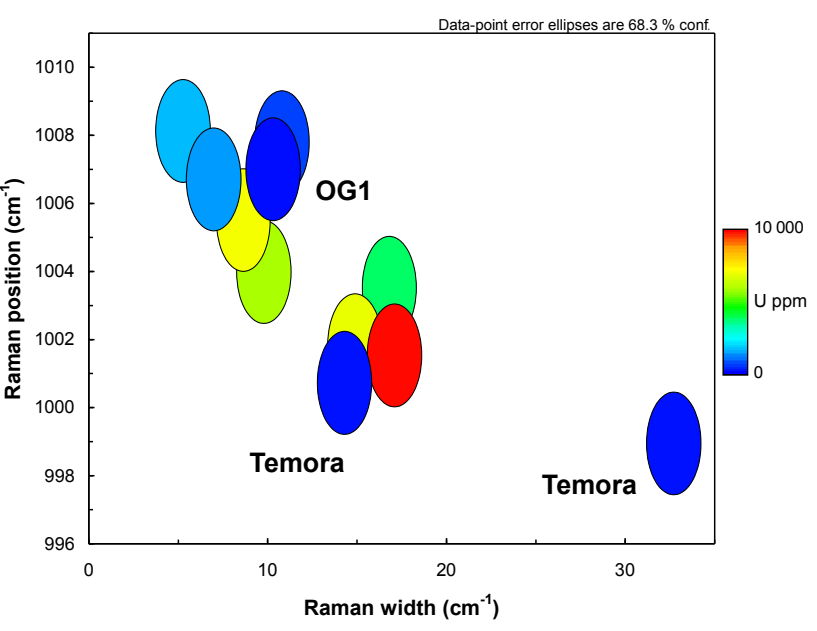

Figure 7. Raman peak position vs. peak width at half height for Raumid zircons and reference zircons OG1 and Temora.

\section{Discussion}

It appears that $\mathrm{UO}_{2}$ isotopologues are in or close to equilibrium in those circumstances where the SIMS $\mathrm{UO}_{x}^{+} / \mathrm{U}^{+}$ based calibration successfully works in the SHRIMP. In general, the $\mathrm{UO}_{2}$ isotopologue disequilibrium data show that in most known situations where the SIMS $\mathrm{UO}_{x}^{+} / \mathrm{U}^{+}$-based calibration breaks down, the $\mathrm{UO}_{2}$ isotopologue disequilibrium also increases. This is consistent with the long-known observation that $\mathrm{Pb}$ ionization is closely related to oxygen availability at the sputter site (Schuhmacher et al., 1993; Schmitt et al., 2010), and that the uranium oxide ratios are an accurate monitor of oxygen availability (Schmitt and Zack, 2012). The $\mathrm{UO}_{2}$ isotopologue deviations show that in the calibration breakdown scenarios previously discovered (Compston et al., 1984; Williams and Hergt, 2000; Wingate and Compston, 2000), the various combinations of uranium and oxygen are, by definition, not in equilibrium with each other. Therefore it is no surprise if they fail to predict the $\mathrm{Pb}^{+}$ionization efficiency.

Similar calibration problems have been reported from smaller radius magnetic sector ion probes (Schmitt et al., 2010; Schmitt and Zack, 2012; Schaltegger et al., 2015). The use of oxygen flooding to enhance $\mathrm{Pb}$ sensitivity in those experiments complicates the repeat of this study in such SIMS instruments, as it adds a third oxygen source (the flood), in addition to the silicate/oxide matrix and the primary beam. However, the reduction of calibration problems in the baddeleyite matrix under flooding conditions (Schmitt et al., 2010) is consistent with the $\mathrm{UO}_{2}$ isotopologue results presented here, which show that the oxygen from the matrix and the primary beam have vastly different behaviour from grain to grain (as evidenced by $\Delta 272$ and $\Delta 274$ deviations in the tens of percent). Sadly, no simple $\Delta 272$ - or $\Delta 274$-based correction puts the baddeleyite data collected here back on 
Table 3. Uranium-thorium-samarium/helium dating results. Italic is a geologically implausible result excluded from interpretation; bold is the helium retention age.

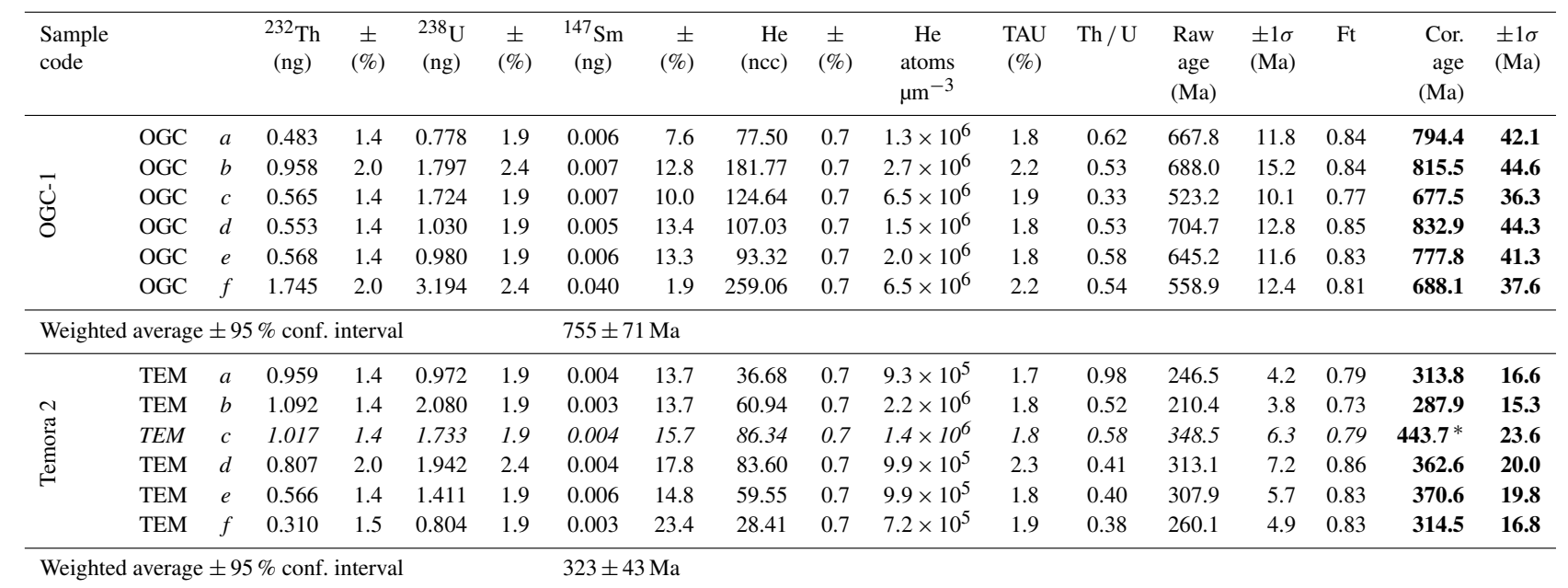

Ft: $\alpha$ recoil correction factor after Farley et al. (1996)

* Outlier identified based on the corresponding U-Pb age.

the calibration line to a useful precision, as the spot-to-spot scatter can only be reduced from $\sim 10$ to $\sim 5 \%$ by applying such a correction. The physical explanation for the observed $\mathrm{UO}_{2}$ isotopologue disequilibrium is still unclear, but a potential candidate is discussed below.

\section{Molecular ion escape model}

It is worth a quick thought experiment to determine whether or not any simple mechanical models can explain the behaviour that we observe. If intact $\mathrm{U}^{16} \mathrm{O}^{+}$ions from the sample are escaping the sputtering site to the mass spectrometer without reacting with other species (as opposed to $\mathrm{U}^{16} \mathrm{O}^{+}$ being formed from the recombination of sputtered atoms), the $\mathrm{U}^{18} \mathrm{O}^{+} / \mathrm{U}^{16} \mathrm{O}^{+}$measured by the mass spectrometer will be lower than that of the sputtering site. As a result, the equilibrium mixture of $\mathrm{UO}_{2}$ species in equilibrium with the (unknown) $\mathrm{U}^{18} \mathrm{O}^{+} / \mathrm{U}^{16} \mathrm{O}^{+}$of the sputtering site will have positive $\Delta 272$ and $\Delta 274$ values relative to the observed $\mathrm{U}^{18} \mathrm{O}^{+} / \mathrm{U}^{16} \mathrm{O}^{+}$.

Should $\mathrm{U}^{16} \mathrm{O}_{2}^{+}$molecules escape from the sputtering surface intact and be counted, then the $\mathrm{U}^{18} \mathrm{O}_{2}^{+} / \mathrm{U}^{16} \mathrm{O}_{2}^{+}$ and $\mathrm{U}^{16} \mathrm{O}^{18} \mathrm{O}^{+} / \mathrm{U}^{16} \mathrm{O}_{2}^{+}$ratios measured by the mass spectrometer would be lower than the equilibrium ratios in the sputtering area, and lower than predictions from the $\mathrm{U}^{18} \mathrm{O}^{+} / \mathrm{U}^{16} \mathrm{O}^{+}$ratio, leading to negative $\Delta 272$ and $\Delta 274$ values like the following:

$$
\begin{aligned}
& \Delta 272=1 /(1-\mathrm{B})-(1+\mathrm{C}) /(1+\mathrm{C}), \\
& \Delta 274=\left(1 /(1-\mathrm{B})^{2} /(1+\mathrm{C})\right)+1,
\end{aligned}
$$

where $\mathrm{B}$ is the fraction of $\mathrm{U}^{16} \mathrm{O}^{+}$which escapes without reaction, and $\mathrm{C}$ is the fraction of $\mathrm{U}^{16} \mathrm{O}_{2}^{+}$which escapes without reacting. As the $\mathrm{U}^{16} \mathrm{O}^{+}$escape curve has a steeper slope than the $\mathrm{U}^{16} \mathrm{O}_{2}^{+}$escape line, combinations of these two mechanisms can produce $\Delta 272$ and $\Delta 274$ values that lie above the $\mathrm{U}^{16} \mathrm{O}_{2}^{+}$escape line in the southwest quadrant of $\Delta 272$ by $\Delta 274$ space, to the left of the $\mathrm{U}^{16} \mathrm{O}^{+}$escape curve in the northeast quadrant of $\Delta 272$ by $\Delta 274$ space, or anywhere in the northwest quadrant. The southeast quadrant is inaccessible via either of these mechanisms in any combination. The prediction of an inaccessible area (positive $\Delta 272$, negative $\Delta 274$ ) is consistent with the observation that not a single analysis lies in this quadrant.

This $\mathrm{U}^{16} \mathrm{O}^{+}$escape curve, the $\mathrm{U}^{16} \mathrm{O}_{2}^{+}$escape line, and the measured $\Delta 272$ and $\Delta 274$ values for baddeleyite analyses are plotted in Fig. 8. These results suggest that if the intact molecular ion escape for matrix $\mathrm{UO}$ and $\mathrm{UO}_{2}$ is responsible for the $\Delta 272$ and $\Delta 274$ deviations, the escaped unreactive ions must be present at the 5 to $20 \%$ level. However, unreactive $\mathrm{UO}_{x}$ species should result in a $\mathrm{UO}_{x}$ production that is high relative to the $\mathrm{Pb}^{+}$production, not low, and baddeleyite miscalibrations can be either high or low relative to the ${ }^{207} \mathrm{~Pb} /{ }^{206} \mathrm{~Pb}$ age. So even at a qualitative level, this hypothesis is somewhat lacking.

The trend towards slightly positive $\Delta 274$ in the $\mathrm{UO}_{2}^{+}$ions is not understood, although for the low-energy ions it may be consistent with a few $\%$ ejection of intact $\mathrm{U}^{16} \mathrm{O}^{+}$ions from the surface. The negative $\Delta 272$ of $\mathrm{UO}_{2}^{+}$ions produced by the 12.5 and $15 \mathrm{kV}$ primary ions is consistent with $\mathrm{UO}_{2}^{+}$and $\mathrm{UO}^{+}$ions being ejected in a $2: 1$ ratio.

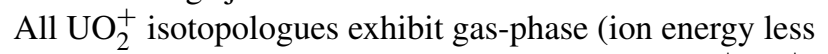
than the extraction potential) tails not present in $\mathrm{UO}^{+}, \mathrm{U}^{+}$, or $\mathrm{Pb}^{+}$ion energy spectra (Fig. 9). This suggests that inferring percentage level or better $\mathrm{U} / \mathrm{Pb}$ ratios using a calibration based on $\mathrm{UO}_{2}^{+}$may be fraught with unforeseen com- 


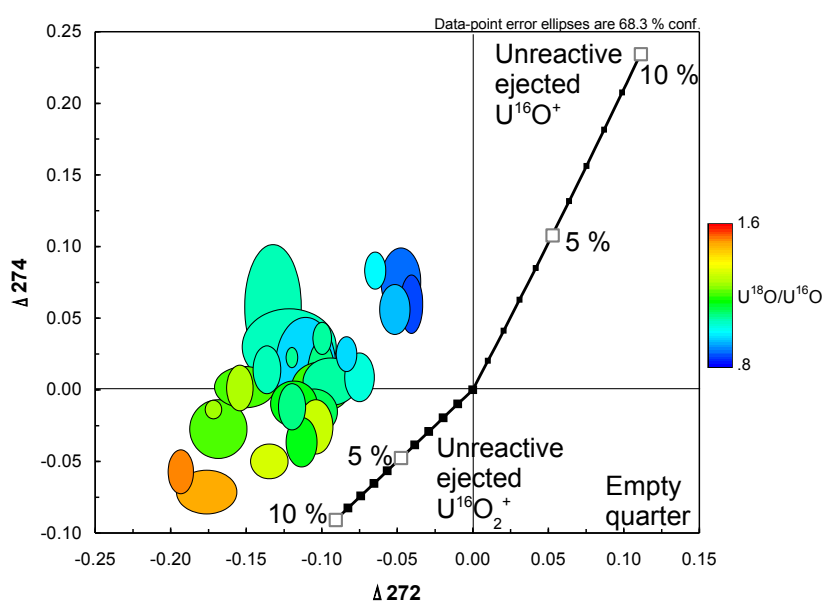

Figure 8. $\Delta 272$ vs. $\Delta 274$ plot for randomly oriented baddeleyite, with predicted trends for unreactive molecule ejection shown. Note that unreacted molecule ejection well in excess of $10 \%$ is required to explain isotopologue deviations of this magnitude.

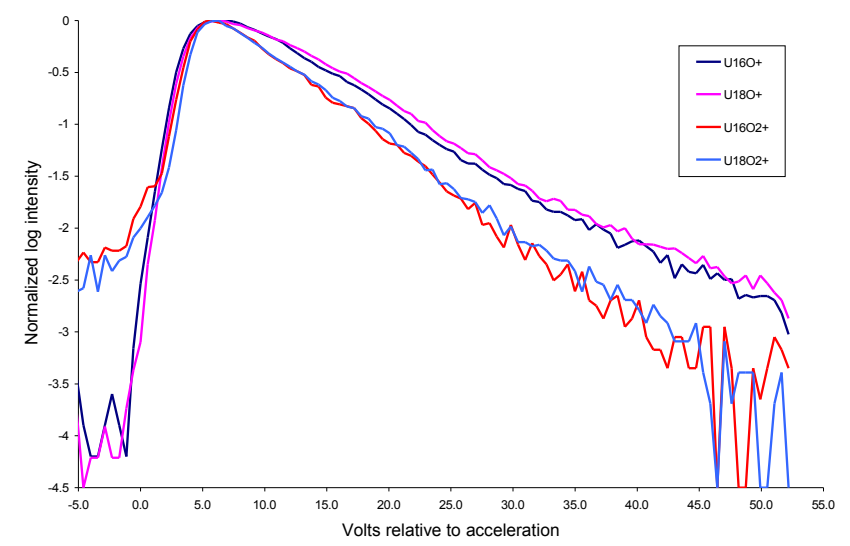

Figure 9. Normalized energy plots for the $\mathrm{UO}^{+}$and $\mathrm{UO}_{2}^{+}$species $\mathrm{U}^{16} \mathrm{O}^{+}, \mathrm{U}^{18} \mathrm{O}^{+}, \mathrm{U}^{16} \mathrm{O}_{2}^{+}$, and $\mathrm{U}^{18} \mathrm{O}_{2}^{+}$. Energy is relative to $10 \mathrm{kV}$ extraction potential. Peak intensities are normalized and plotted in $\log$ scale. Note that the $\mathrm{UO}_{2}$ ions have a population with negative initial energy not present in the UO species.

plications compared with the traditional $\mathrm{UO}^{+}$-based calibration. An additional complication may occur for $\mathrm{UO}_{2}^{+}$-based calibrations at impact energies greater than $10 \mathrm{keV}$, if intact matrix $\mathrm{UO}_{2}^{+}$ejection is occurring and masking the oxygen availability for $\mathrm{Pb}$ ionization enhancement.

\section{High-uranium effect}

The $\sim 36$ Ma Raumid and $\sim 180$ Ma Red Hill (Williams and Hergt, 2000; White and Ireland, 2012) zircons show a $\Delta 274$ excess up to about 0.1. However, the 0.8 Ma Bishop Tuff zircons, which do not seem to exhibit this high-uranium effect (Chamberlain et al., 2014; Ickert et al., 2015), have only one analytical spot with a $\Delta 274$ above 0.025 , and none above

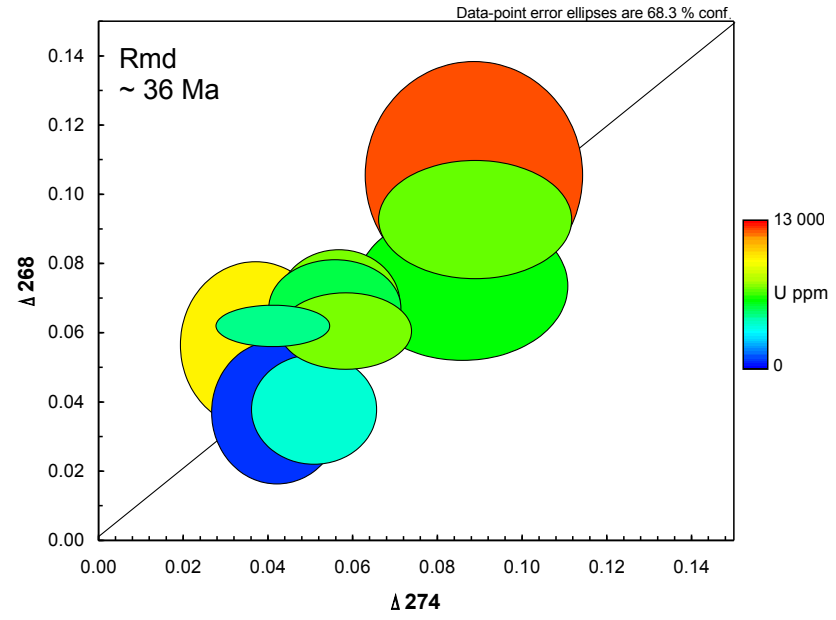

Figure 10. $\Delta 274$ vs. $\Delta 268$ plot for Raumid zircon. This plot shows that the dioxide disequilibrium is the same for Th and $\mathrm{U}$ oxides, so that the metal phase is unlikely to have much of a role in isotopologue formation.

0.05. A comparison of $\Delta 274$ and $\Delta 268$ in the Raumid zircons show that both the uranium and the thorium isotopologues show similar behaviour (Fig. 10). Thus the effect is probably unrelated to the higher potential valence states of uranium.

Raman measurements were made on the Raumid grains in order to determine whether any lattice damage parameters could be identified that may relate to the production of a $\Delta 274$ excess (Fig. 7). White and Ireland (2012) have shown that Jurassic high-U zircons which show an apparent U-concentration effect are metamict, according to the spectral featured described in Nasdala et al. (1995).

Depending of the degree of radiation damage, Raman spectroscopy can be used to measure the degree of metamictization in zircons (Nasdala et al., 1995). Well-ordered zircons show narrow internal and external vibrational bands in the spectral range below $1100 \mathrm{~cm}^{-1}$ (for band assignments, see Dawson et al., 1971). With increasing metamictization, all main Raman bands decrease in intensity, become increasingly broader, and shift towards lower wavenumbers. These changes are due to decreasing short-range order in the radiation-damaged zircon (Nasdala et al., 2004). In the case of natural zircons, decreased short-range order is mainly caused by radiation damage. However, the presence of several wt $\% \mathrm{U}$ and $\mathrm{Th}$ may also decrease the short-range order and cause detectable effects on the Raman band width. This has been demonstrated by Podor (1995) for synthetic rareearth monazites.

The Raman results show slight $1007 \mathrm{~cm}^{-1}$ peak broadening in the high-U Raumid samples relative to the low-U samples. However, The highest $\mathrm{U}$ grains are barely broader than the OG-1 analysis, and none of the Raumid Raman results show band widths as wide as the Temora zircon (Fig. 11). 


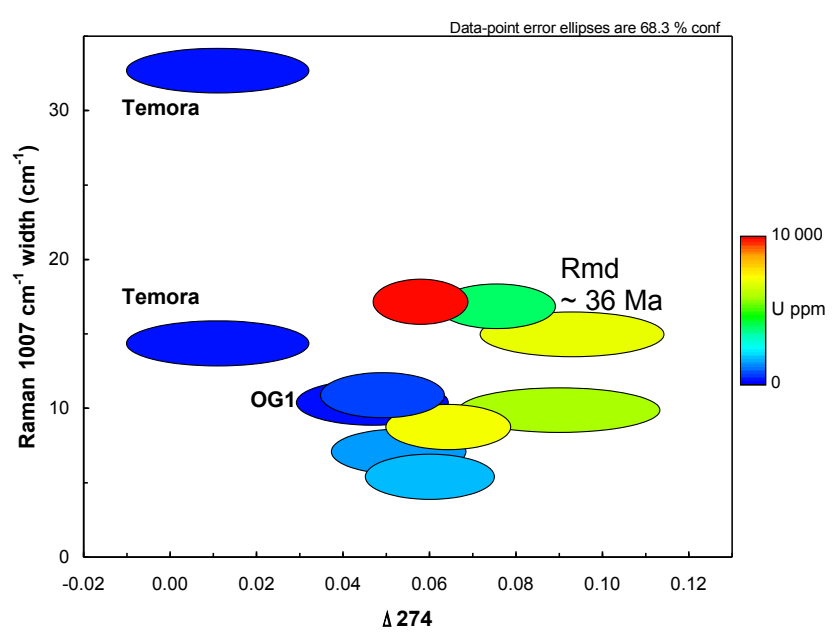

Figure 11. Comparison of $\Delta 274$ vs. Raman peak width for selected $\sim 37$ Ma Raumid zircon grains. Standard reference zircons OG1 and Temora are shown for comparison.

The (U-Th-Sm) / He data show that the Palaeoarchean OG1 standard zircons have a Neoproterozoic He age, making their cooling age about twice as old as the Temora grains, instead of 8 times older. The He content of the OG-1 zircons is, on average, about 3 times that of Temora (Table 3). So it is unlikely that radiation dose alone explains the broader Raman peak in Temora relative to OG-1 or Raumid. Despite the "high-U" effect of excess apparent ${ }^{206} \mathrm{~Pb}$ being present in the Raumid sample, there is no evidence of metamictization. The absence of a "high-U effect" in the Pleistocene Bishop Tuff, combined with the presence of a "high-U effect" and the $\Delta 274$ and $\Delta 268$ anomalies in the Eocene Raumid zircons with relatively low levels of Raman broadening, suggests that the $\Delta 274$ anomaly is a more sensitive indicator of a high-U effect than the $1005 \mathrm{~cm}^{-1}$ Raman peak width, and that the radiation dose in the zircon required to trigger the "high-U effect" is relatively small.

There is some debate as to whether or not the zircon selfannealing temperature is at the $\sim 200^{\circ} \mathrm{C} \mathrm{He}$ closure temperature (Weber et al., 1997), or up in the greenschist facies around the biotite closure temperature (Pidgeon, 2014). However, for the Temora and OG1 results described here, this is irrelevant. The Biotite Ar closure time of the Middledale Gabbro (host of the Temora zircons) cannot be older than the crystallization age of $417 \mathrm{Ma}$ (Black et al., 2004). The Ar-in-biotite closure temperature for the Owen's Gully diorite (OG1) cannot be younger than the He age presented here. So just like the He age, the biotite Ar age of OG1 must be significantly older than that of Temora. Further investigation of the Raman behaviour of Temora zircons would be a good idea, to ascertain whether this particular grain was an outlier, or whether there is a non-radiation component of peak broadening.
In terms of radiation damage, a Bishop Tuff zircon would have one decay chain per $1700 \mathrm{~nm}^{3}$, while a Raumid zircon of the same $U$ concentration would have one per $3700 \mathrm{~nm}^{3}$. This is a similar dosage to a $200 \mathrm{ppm}$ zircon of $1 \mathrm{Ga}$ age, and such zircons show no trace of the high-uranium effect.

\section{Conclusions}

When using an isotopically labelled oxygen primary beam, the ratio of beam/sample oxygen in oxide species can be used to predict the ratio of dioxide species. For $\mathrm{UO}$ and $\mathrm{UO}_{2}$ in minerals of geochronological interest, these predictions are close in systems where SIMS geochronology works well, but show large deviations in systems such as baddeleyite dating, high-uranium zircon, and repetitive downhole measurements, where $\mathrm{U}-\mathrm{Pb}$ geochronology has poor accuracy. This is consistent with the $\mathrm{UO}_{x}$ term in the U-Pb calibration being a monitor of oxygen availability for $\mathrm{Pb}^{+}$ion production, as if various UO species can be shown to be out of disequilibrium with each other, then it is unlikely that any particular one will be useful for predicting the oxygen-based enhancement of $\mathrm{Pb}$ ion formation.

The excess in $\Delta 274$ appears to correlate with the highuranium effect which causes erroneously old SIMS U-Pb ages better than crystal lattice damage, as determined by the broadening of the $1005 \mathrm{~cm}^{-1}$ Raman band. The cost of the ${ }^{18} \mathrm{O}_{2}$ gas ( $\sim$ USD 750 per litre) might prevent routine use for analysing zircons where the SIMS high-U effect might be present, but as the duoplasmatron uses only a few tens of millilitres per day, it is not inconceivable that this technique could be used on zircons with ages intermediate between the $\sim 37 \mathrm{Ma}$ Raumid and the $0.8 \mathrm{Ma}$ Bishop Tuff, to ascertain when the high-U effect is initiated, and what other crystallographic features might be associated with it.

Data availability. The Supplement contains all the data from every analysis used in this paper.

\section{The Supplement related to this article is available online at https://doi.org/10.5194/gi-6-523-2017-supplement.}

Competing interests. The authors declare that they have no conflict of interest.

Acknowledgements. We thank Trevor Ireland, Michael Wingate, and Yuri Kostitsyn for the loan of samples; Simon Bodorkos for help with the SQUID data reduction software, Patrick Burke for SHRIMP technical assistance; Chris May (TSW Analytical) for help with the solution ICP-MS work; and the management of Australian Scientific Instruments for allowing the publication 
of this in-house research. Martin Danišík was supported by the AuScope NCRIS2 programme, Australian Scientific Instruments Pty Ltd., Australian Research Council (ARC) Discovery funding scheme (DP160102427), and Curtin Research Fellowship. We thank Kenji Horie and Trevor Ireland for constructive reviews.

Edited by: Lev Eppelbaum

Reviewed by: Kenji Horie and Trevor Ireland

\section{References}

Aleinikoff, J. N., Schenck, W. S., Plank, M. O., Srogi, L., Fanning, C. M., Kamo, S. L., and Bosbyshell, H.: Deciphering igneous and metamorphic events in high-grade rocks of the Wilmington Complex, Delaware: Morphology, cathodoluminescence and backscattered electron zoning, and SHRIMP U-Pb geochronology of zircon and monazite, Geol. Soc. Am. Bull., 118, 39-64, 2006.

Black, L. P., Kamo, S. L., Allen, C. M., Davis, D. W., Aleinikoff, J. N., Valley, J. W., Mundil, R., Campbell, I. H., Korsch, R. J., Williams, I. S., and Foudoulis, C.: Improved ${ }^{206} \mathrm{~Pb} / 238 \mathrm{U}$ microprobe geochronology by the monitoring of a trace-elementrelated matrix effect; SHRIMP, ID-TIMS, ELA-ICP-MS and oxygen isotope documentation for a series of zircon standards, Chem. Geol., 205, 115-140, 2004.

Carson, C. J., Worden, K. E., Scrimgeour, I. R., and Stern, R. A.: The Palaeoproterozoic evolution of the Litchfield Province, western Pine Creek Orogen, northern Australia: Insight from SHRIMP U-Pb zircon and in situ monazite geochronology, Precambrian Res., 166, 145-167, 2008.

Chamberlain, K. J., Wilson, C. J. N., Wooden, J. L., Charlier, B. L. A., and Ireland, T. R.: New Perspectives on the Bishop Tuff from Zircon Textures, Ages and Trace Elements, J. Petrol., 55, 395-426, 2014.

Claoué-Long, J., Compston, W., Roberts, J., and Fanning, C. M.: Two Carboniferous ages: a comparison of SHRIMP zircon dating with conventional zircon ages and ${ }^{40} \mathrm{Ar} /{ }^{39} \mathrm{Ar}$ analysis, in: Geochronology Time Scales and Global Stratigraphic Correlation, edited by: Berggren, W. A., Kent, D. V., Aubrey, M. P., and Hardenbol, J., Society for Sedimentary Geology, SEPM Special Publication No. 54, 3-21, 1995.

Claoué-Long, J., Maidment, D., and Donnellan, N.: Stratigraphic timing constraints in the Davenport Province, central Australia: A basis for Palaeoproterozoic correlations, Precambrian Res., 166, 204-218, 2008.

Compston, W., Williams, I. S., and Meyer, C.: U-Pb geochronology of zircons from lunar breccia 73217 using a sensitive high massresolution ion microprobe, J. Geophys. Res., 89, B525-B534, 1984.

Danišík, M., Štěpančíková, P., and Evans, N. J.: Constraining long-term denudation and faulting history in intraplate regions by multisystem thermochronology: An example of the Sudetic Marginal Fault (Bohemian Massif, central Europe), Tectonics, 31, TC2003, https://doi.org/10.1029/2011TC003012, 2012.

Dawson, P., Hargreave, M. M., and Wilkinson, G. R.: The vibrational spectrum of zircon $\left(\mathrm{ZrSiO}_{4}\right)$, J. Phys. C Solid State, 4 , 240-256, 1971.
Farley, K. A., Wolf, R. A., and Silver, L. T.: The effects of long alpha-stopping distances on (U-Th)/He ages, Geochim. Cosmochim. Ac., 60, 4223-4229, 1996.

Fletcher, I. R., McNaughton, N. J., Davis, W. J., and Rasmussen, B.: Matrix effects and calibration limitations in ion probe $\mathrm{U}-\mathrm{Pb}$ and Th-Pb dating of monazite, Chem. Geol., 270, 31-44, 2010.

Franzreb, K., Lörinčík, J., and Williams, P.: Quantitative study of oxygen enhancement of sputtered ion yields. I. Argon ion bombardment of a silicon surface with $\mathrm{O}_{2}$ flood, Surf. Sci., 573, 291309, 2004.

Froude, D. O., Ireland, T. R., Kinny, P. D., Williams, I. S., Compston, W., Williams, I. R., and Myers, J. S.: Ion microprobe identification of 4100-4200 Myr-old terrestrial zircons, Nature, 304, 616-618, 1983.

Gregory, C. J., Rubatto, D., Allen, C. M., Williams, I. S., Hermann, J., and Ireland, T.: Allanite micro-geochronology: A LA-ICP-MS and SHRIMP U-Th-Pb study, Chem. Geol., 245, 162-182, 2007.

Guenthner, W. R., Reiners, P. W., Ketcham, R. A., Nasdala, L., and Giester, G.: Helium diffusion in natural zircon: Radiation damage, anisotropy, and the interpretation of zircon (U-Th)/He thermochronology, Am. J. Sci., 313, 145-198, 2013.

Ickert, R. B., Hiess, J., Williams, I. S., Holden, P., Ireland, T. R., Lanc, P., Schram, N., Foster, J. J., and Clement, S. W.: Determining high precision, in situ, oxygen isotope ratios with a SHRIMP II: Analyses of MPI-DING silicate-glass reference materials and zircon from contrasting granites, Chem. Geol., 257, 114-128, 2008.

Ickert, R. B., Mundil, R., Magee Jr., C. W., and Mulcahy, S. R.: The U-Th-Pb systematics of zircon from the Bishop Tuff: A case study in challenges to high-precision $\mathrm{Pb} / \mathrm{U}$ geochronology at the millennial scale, Geochim. Cosmochim. Ac., 168, 88-110, 2015.

Ireland, T. R., Clement, S., Compston, W., Foster, J. J., Holden, P., Jenkins, B., Lanc, P., Schram, N., and Williams, I. S.:, Development of SHRIMP, Aust. J. Earth Sci., 55, 937-954, 2008.

Kilner, J. A., De Souza, R. A., and Fullarton, I. C.: Surface exchange of oxygen in mixed conducting perovskite oxides, Solid State Ionics, 86-88, 703-709, 1996.

Kostitsyn, Y. A., Volkov, V. N., and Zhuravlev, D. Z.: Trace elements and evolution of granite melt as exemplified by the Raumid Pluton, Southern Pamirs, Geochem. Int., 45, 971-982, 2007.

Laurie, J. R., Bodorkos, S., Nicoll, R. S., Crowley, J. L., Mantle, D. J., Mory, A. J., Wood, G. R., and Smith, T. E.: Calibrating the middle and late Permian palynostratigraphy of Australia to the geologic time-scale via U-Pb zircon CA-IDTIMS dating, Aust. J. Earth Sci., 63 701-730, 2016.

Ludwig, K.: SQUID 2: a user's manual, Berkeley Geochronology Center, Berkeley Geochronology Center Special Publication 5, 110 pp., 2010.

Magee, C., Ferris, J., and Magee, C.: Effect of impact energy on SIMS U-Pb zircon geochronology, Surf. Interface Anal., 46, 322-325, 2014.

Magee, C. W., Withnall, I. W., Hutton, L. J., Perkins, W. G., Donchak, P. J. T., Parsons, A., Blake, P. R., Sweet, I. P., and Carson, C. J.: Joint GSQ-GA geochronology project, Mount Isa Region, 2008-2009, Geological Survey of Queensland, 134 pp., 2012.

Manning, P. S., Sirman, J. D., De Souza, R. A., and Kilner, J. A.: The kinetics of oxygen transport in $9.5 \mathrm{~mol} \%$ single crystal yttria stabilised zirconia, Solid State Ionics, 100, 1-10, 1997. 
Matsuda, H.: Double focusing mass spectrometers of second order, International Journal of Mass Spectrometry and Ion Physics, 14, 219-233, 1974.

Nasdala, L., Irmer, G., and Wolf, D.: The degree of metamictization in zircon: a Raman spectroscopic study, Eur. J. Mineral., 7, 471478, 1995 .

Nasdala, L., Wenzel, M., Vavra, G., Irmer, G., Wenzel, T., and Kober, B.: Metamictisation of natural zircon: accumulation versus thermal annealing of radioactivity-induced damage, Contrib. Mineral. Petr., 141, 125-144, 2004.

Pidgeon, R. T.: Zircon radiation damage ages, Chem. Geol., 367, 13-22, 2014.

Podor, R.: Raman spectra of the actinide-bearing monazites, Eur. J. Mineral., 7, 1353-1360, 1995.

Schaltegger, U., Schmitt, A. K., and Horstwood, M. S. A.: U-Th$\mathrm{Pb}$ zircon geochronology by ID-TIMS, SIMS, and laser ablation ICP-MS: Recipes, interpretations, and opportunities, Chem. Geol., 402, 89-110, 2015.

Schmitt, A. K. and Zack, T.: High-sensitivity U-Pb rutile dating by secondary ion mass spectrometry (SIMS) with an $\mathrm{O}_{2}^{+}$primary beam, Chem. Geol., 332-333, 65-73, 2012.

Schmitt, A. K., Chamberlain, K. R., Swapp, S. M., and Harrison, T. M.: In situ U-Pb dating of micro-baddeleyite by secondary ion mass spectrometry, Chem. Geol., 269, 386-395, 2010.

Schuhmacher, M., de Chambost, E., McKeegan, K. D., Harrison, T. M., and Migeon, H.: In situ dating of zircon with the CAMECA ims 1270, edited by: Benninghoven, A., Secondary Ion Mass Spectrometry, SIMS IX, 919-922, 1994.

Sobers Jr., R. C., Franzreb, K., and Williams, P.: Quantitative measurement of $\mathrm{O} / \mathrm{Si}$ ratios in oxygen-sputtered silicon using ${ }^{18} \mathrm{O}$ implant standards, Appl. Surf. Sci., 231-232, 729-733, 2004.

Stern, R. A. and Amelin, Y.: Assessment of errors in SIMS zircon $\mathrm{U}-\mathrm{Pb}$ geochronology using a natural zircon standard and NIST SRM 610 glass, Chem. Geol., 197, 111-142, 2003.
Stern, R. A. and Berman, R. G.: Monazite $\mathrm{U}-\mathrm{Pb}$ and $\mathrm{Th}-\mathrm{Pb}$ geochronology by ion microprobe, with an application to in situ dating of an Archean metasedimentary rock, Chem. Geol., 172, 113-130, 2001.

Stern, R. A., Bodorkos, S., Kamo, S. L., Hickman, A. H., and Corfu, F.: Measurement of SIMS Instrumental Mass Fractionation of $\mathrm{Pb}$ Isotopes During Zircon Dating, Geostand. Geoanal. Res., 33, 145-168, 2009.

Taylor, R., Clark, C., and Reddy, S. M.: The effect of grain orientation on secondary ion mass spectrometry (SIMS) analysis of rutile, Chem. Geol., 300-301, 81-87, 2012.

Weber, W. J., Ewing, R. C., and Meldrum, A.: The kinetics of alphadecay-induced amorphization in zircon and apatite containing weapons-grade plutonium or other actinides, J. Nucl. Mater., 250, 147-155, 1997.

White, L. T. and Ireland, T. R.: High-uranium matrix effect in zircon and its implications for SHRIMP U-Pb age determinations, Chem. Geol., 306-307, 78-91, 2012.

Williams, I. S.: U-Th-Pb Geochronology by Ion Microprobe, in: Applications of microanalytical techniques to understanding mineralizing processes, edited by: McKibben, M. A., Shanks III, W. C., and Ridley, W. I., Rev. Econ. Geol., 7, 1-35, 1998.

Williams, I. S. and Hergt, J.: U-Pb dating of Tasmanian dolerites: a cautionary tale of SHRIMP analysis of high-U zircon, in: Beyond 2000: New Frontiers in Isotope Geoscience, Lorne, edited by: Woodhead, J. D., Hergt, J. M., and Noble, W. P., 185-188, 2000.

Wingate, M. T. D. and Compston, W.: Crystal orientation effects during ion microprobe $\mathrm{U}-\mathrm{Pb}$ analysis of baddeleyite, Chem. Geol., 168, 75-97, 2000. 